\title{
NATIVE SYNTAX AND TRANSLATION EFFECTS: ADNOMINAL ARGUMENTS IN THE GREEK AND LATIN NEW TESTAMENT
}

\author{
CHIARA GIANOLLO \\ University of Konstanz
}

ABSTRACT

A comparative study of the syntax of adnominal arguments in the Greek original and in the Latin Vulgate translation of the Gospels shows that word order in this domain is strikingly parallel in the two languages. The fact that faithfulness in translating evidently extends to syntax, leveling Latin to the Greek model, must not lead to the conclusion that the language of the Latin translation is artificially shaped in conformity to the Greek; rather, it shows that Latin, at this diachronic stage, shared with New Testament Greek some significant parametric settings pertaining to nominal syntax.

\section{[1] INTRODUCTION}

\section{[1.1] The focus of this work}

Bible translations offer to the linguist a unique opportunity to investigate a natural parallel corpus characterized by a potentially optimal combination of factors, among which the homogeneity of pragmatic contexts and the expected faithfulness on the part of the translator are of particular import to syntactic investigation.

However, scholars are also well aware of the main impediment which often frustrates their attempts when dealing with this class of documents: faithfulness in translating sacred texts, because of the awe of the model felt by the translators and by the community they serve, typically proceeds so far as to override in many important respects the native characteristics of the translation's language. Thus, for instance, Plater \& White $(1926,29)$ remark upon the 'almost slavish literalness' of the Old Latin translations of biblical texts and even suggest that the earliest Latin versions might have been interlinear translations of the Greek original. Metzger (1977, 323) expresses a particularly definite stand in this respect: 'The style of the translation in pre-Jerome versions is totally lacking in polish, often painfully literal, and occasionally even of dubious Latinity. It is not difficult to understand how such characteristics arose from interlinear renderings of the Greek text which sought to preserve the letter of the sacred text. Such concern led to many important consequences, the first being a strong exotic quality in both vocabulary and syntax.' 
Bible translations are, thus, a class of texts for which distinguishing between features of native syntax and features arising through interference by translation effects is a particularly complex task. Moreover, in the case of Latin, a further complicating factor is represented by the intricate socio-linguistic setting from which the translations originate. By the last decades of the 4th century-when Jerome was working at the Vulgata-the divide between the standard classicist language and sub-élite registers had become deep (cf. Adams 2003, esp. chapter 8, for an overview). Often 'exotic' constructions and lexical items occurring in biblical translations turn out to find parallels in contemporary documents written in the 'colloquial register of the educated' (Clackson \& Horrocks 2007, 286), i.e. the sermo humilis which was gaining a broader written representation in connection to the social and cultural changes brought about by the Christian revolution. That is, some linguistic peculiarities that had previously been attributed to translation effects, or to a special register of 'Christian Latin', can better be interpreted as properties of the evolving native language (cf. Clackson \& Horrocks 2007, 284-292 for discussion).

In this paper I present an attempt to distinguish between translation effects and native syntax in the case of one specific phenomenon: the distribution of genitives expressing adnominal arguments in the late variety of Latin used in the Vulgata translation from the Greek. The focus on this phenomenon is motivated by two observations. On the one hand, a sensible differentiation in the linear ordering of genitives with respect to the Classical Latin situation can be observed: while Classical Latin is characterized by a mixed GN/NG system, the variety used in the Vulgata presents an overwhelmingly NG ordering (cf. section [2]). On the other hand, this state of affairs finds a remarkable correspondence in the distribution of genitives found in the Greek original (cf. section [3]).

The question which arises here is whether the Latin NG order has to be explained as a direct effect of the Greek model. I will argue that the similarities in the syntax of genitives between New Testament Greek and Latin find a stylistic motivation in the ideological criteria governing the translation technique of sacred texts, but also represent a grammatically significant phenomenon, in that they are brought about by 'natural' changes affecting the native syntax of Latin.

My empirical basis is represented by (i) a quantificational evaluation of translation effects by means of a comparative study of the language of the four Gospels in the Greek original and in the Vulgata translation (section [3]); (ii) a comparison of the data coming from the Vulgata with those of earlier and contemporary Latin texts, commonly considered instances of the 'new' colloquial register (section [4]).

The examination of the first set of evidence will show that, although the parallelism between the Greek and the Latin texts in the realization of adnominal arguments is largely predominant, a particular Greek construction can be singled out, where variation with respect to the model appears to be significant in the Latin version. This construction, which involves genitive extraposition and reanalysis at 
a clausal level, is perceived by the Latin translator as alien to his native competence, and is therefore not straightforwardly reproduced in the Latin word order.

The comparison with non-translated texts, on the other hand, will demonstrate that the NG order found in the Vulgata finds a parallel in earlier and contemporary native documents. This hints to the existence of a 'real' syntactic change, i.e. to a profound reorganization of the internal structure of the nominal phrase, moving from the mixed GN/NG grammar of Classical Latin to the NG grammar of Late Latin. Accordingly, I will propose that the NG order found in the Vulgata is not the ephemeral result of interference through translation effects, but is consistent with a more general tendency of the non-conservative colloquial register, which can be argued to have been so pertinacious as to be transmitted to the Romance languages.

\section{[1.2] The Latin text}

Methodological advances in the diachronic study of syntax strongly point to the importance of adopting an I-language perspective when dealing with historical data: ideally, even when working with closed written corpora, the primary goal of the investigation should consist in the description of individual systems of linguistic competence, of the mental grammars of single speakers, as the only scientifically approachable entities (cf. Lightfoot 2006, Crisma \& Longobardi 2009). Only once (modules of) individual mental grammars have been adequately described, is it possible to proceed further in accounting for variation within linguistic communities, and for its import in the process of language change. This task is particularly difficult when dealing with texts of such a complex history as the Gospels in the Vulgata translation.

The extent to which they represent an individual competence, namely Jerome's, is a matter of endless debate. If it is true that Jerome 'was destined to fix the literary form of the Bible of the entire Western Church' (Metzger 1977, 332), it is also necessary to consider that he relied on previous translations of the Gospels, which go under the name of old Latin, and which are of a very heterogeneous nature. To quote Metzger again, 'the Old Latin was a living creature, constantly growing' (ib., 325).

In his address to Pope Damasus, Jerome explicitly declares the twofold aim which guides his revision of the Old Latin translations: to correct mistakes in interpretation and to base the Latin version on the best Greek textual tradition. ${ }^{1}$ The excellence of his achievements in both respects is commonly acknowledged by New Testament scholarship. However, there is also agreement on the fact that Jerome did not translate the Gospels anew, but rather revised the Old Latin versions (cf. Metzger 1977, 352-362, Aland \& Aland 1989, 191, Elliott 1992). His original work as translator is clearly detectable only in those Old Testament canonical books that he translated directly from the Hebrew. No consensus, on the other hand, is reached

[1] Hier., Praefatio Sancti Hieronymi Presbyteri in Evangelio, Weber et al. (1994, 1515f.). 
on the precise evaluation of Jerome's revision in the case of the language of the old Latin Gospels, and especially on Jerome's actual responsibility for most grammatical choices. While systematic substitutions of lexical items are relatively easy to detect (cf. among others Meershoek 1966, Burton 2000, 191-199), it is much more complicated to assess Jerome's responsibility for specific constructions and word-order patterns. Just to give an example of two extreme views on the topic, according to Plater \& White (1926, 29), Jerome did not change the 'slavish' literalness of the Old Latin Gospels. Burton $(2000,192)$, on the other hand, goes as far as to suggest that, in translating, 'Jerome's technique in the Vulgate Gospels is often more literal than that of his Old Latin models', and he adduces evidence for motivated differences in word order between the Old Latin texts and Jerome's Vulgate (Burton 2000, 197f.). Metzger $(1977,353)$ reports H. J. Vogels' calculations, according to which Jerome would have changed the Latin translation in approximately 3,500 passages, for both stylistic and philological reasons. These quantificational efforts, however, must be considered tentative, in light of the fact that there is no certainty with respect to both the Old Latin and the Greek text(s) used by Jerome (cf. Metzger 1977, 352-374, Aland \& Aland 1989, 190-192).

From this very cursory introduction it should be clear that the task of carrying out an examination of Jerome's translation technique has to deal with some serious issues concerning the state of the available documentation. Another problem is represented by Jerome's multifaceted competence of Latin: as will be discussed in section [4], the language used in biblical translations differs from the register adopted in Jerome's literary production in some important respects, including word order and the frequency of discontinuous constituents. In principle, this fact could be interpreted in two opposite ways: as proving the artificialness of the Latin biblical language, or as witnessing a situation of diglossia, whereby two distinct varieties stemming from the same language co-exist as structurally and functionally separate systems within a community and, often, within the competence of individual speakers.

My data suggest that this second explanation is on the right track, and that the heterogeneity observable in Jerome's corpus of works is due to the fact that he mastered two distinct varieties of Latin, one governed by the system of rules of Classical Latin, and the other one represented by the 'new' sermo humilis, i.e. the colloquial, sub-élite variety (cf. also Adams 1976, 82-83, for a similar perspective on the problem). However, a thorough discussion of Jerome's diglossia would require the exam of a much wider sample of texts and, especially, linguistic phenomena, in order to assess whether we are dealing with a difference between stylistic registers or rather between grammatical systems. I will therefore start from a somewhat weaker stance, which will be further motivated in section [2]: I will assume that Jerome will have included in the translation of the Gospels that he edited only constructions which he considered to be grammatical, although maybe far from the stylistic register in 
which he had been educated in his classicist rhetorical training. In this way, we can consider Jerome's language in the Vulgate as an I-language, i.e. as a system of principles and parameter settings.

\section{[1.3] Criteria for data collection}

In order to come as close as possible to Jerome's original version of the Vulgate, the edition used for data collection in this work is the Stuttgart Vulgate (Weber et al. 1994). ${ }^{2}$ In collecting data on genitive constructions, I adopted the following criteria: $^{3}$

(1) a. in general, only genitives which semantically qualify as arguments of the nominal head (possessive, subjective and objective genitives) or which instantiate a contextually determined relation with the head noun (a subclass of epexegetical genitives) are included;

b. partitive genitives and genitives of quality are not in the corpus;

c. genitives and possessive adjectives are counted separately;

d. only constructions where the head is a noun are counted (e.g. no genitives which depend on verbs or adjectives);

e. items which occur in nominal phrases with a gapped noun (ellipsis) are disregarded;

f. items which are discontinuous with respect to their head noun are not counted.

The semantic restrictions imposed on the search (1a)-(1b) are motivated by crosslinguistic evidence pointing to a different structural configuration for the DPs containing arguments or quasi-arguments and the DPs containing the genitive constituents excluded from the corpus. In particular, partitive genitives enter into a quantificational structure, where they express the set over which the head of the construction quantifies. Genitives of quality are instead attributive adjuncts.

Examples of argumental genitives are given in (2a)-(2c), displaying respectively a possessive, a subjective, and an objective genitive. The two latter types are most often found with deverbal nominalizations:

[2] Due to this choice, many of the cited examples display orthographical conventions which are likely to be unfamiliar to some readers, such as for instance the absence of punctuation, the use of lower case for ethnic adjectives, some inconsistency with proper names. This stems from the decision of the Stuttgart Vulgate's editors to conservatively mirror in the text the orthography of Mediaeval manuscripts. The English translations of the New Testament passages generally correspond to the Revised Standard Version, but are sometimes modified to provide a more literal rendering. The Greek text follows the Nestle-Aland edition (Nestle et al. 1993).

[3] I will use the following abbreviations, most of which are standard in typological studies and formal syntactic research: D: determiner (article); A: adjective; G: genitive; $G^{\text {agr }}$ : possessive adjective; N: noun; P: phrase; DP: determiner phrase (nominal phrase). 
(2) a. in domo Simonis leprosi

'in the house of Simon the leper' (Mt 26:6)

b. in praedicatione Ionae

'at the preaching of Jonah' (Mt 12:41)

c. a constitutione mundi

'since the foundation of the world' (Mt 13:35)

It is in many cases debatable whether epexegetical genitives ('génitif explicatif ou de définition' in Ernout \& Thomas 1953, 'appositive genitive' in Blass \& Debrunner 1961) qualify as quasi-arguments or rather as attributive adjuncts. The class of uses subsumed under this label by the grammars is quite heterogeneous, as insightfully discussed by de Groot (1957). I included in my collection only a subset of what is traditionally comprised in the category, namely those genitives which have with the head noun a relation that can be paraphrased as "belonging to $\mathrm{N}$, having to do with $\mathrm{N}$ ', i.e. a relation similar to that of possession (what de Groot 1957 calls 'conjunctive genitive'). Examples are given in (3):

(3) a. vestimentum de pilis camelorum

'clothing made of camel's hair'(Mt 3:4)

b. lilia agri

'the lilies of the field' (Mt 6:28)

c. tempus fructuum

'the time of the fruits' (Mt 21:34)

The reason for including, in addition to purely argumental genitives, also this subset of epexegetical genitives lies in (i) the fact that genitives expressing such generic relation or connection to the head noun have been shown by cross-linguistic research to have the same structural characteristics as possessive, subjective, and objective genitives (see Giorgi \& Longobardi 1991, who apply to this kind of genitives the notion of 'R-relation', which partially overlaps with the traditional notion of epexegetical genitive); (ii) the practical problem encountered when trying to consistently distinguish between possessive and epexegetical genitives, since the two interpretations are often difficult to tell apart. In order to avoid arbitrary choices, it seemed preferable to include them in the corpus.

The exclusion, on the other hand, of genitives of quality may be argued to lead to an underestimation of Greek influence on Latin syntax. It is often noticed, in fact, that the frequency of this kind of construction was substantially enhanced by its presence in the Greek model, in turn heavily influenced by Hebrew in this respect (cf. Plater \& White 1926, 93, Blass \& Debrunner 1961, 91f.).

Although I don't have precise quantitative data on this, it can safely be said that the inclusion of genitives of quality, and of partitive genitives, would not lead to change the estimate of the overwhelming tendencies observable in the linear or- 
dering of genitive constituents. Here, however, the focus of interest with respect to genitive constituents is represented by their function as expression of adnominal arguments or quasi-arguments. It is therefore preferable to keep the data sample homogeneous in this respect. ${ }^{4}$

A comment is also in order with respect to the issue of discontinuity (1f). First, it is necessary to distinguish between discontinuity proper (linear order of the DP disrupted by the occurrence of DP-external elements) and non-adjacency (occurrence of other DP-internal elements in between the head and the adjective or the genitive). If the latter phenomenon is very important in order to detect the relative ordering of constituents and, thus, the internal syntactic configuration of the Latin DP, only the former qualifies as hyperbaton, i.e. as a displacement operation motivated by discourse factors at the clausal level. Thus, for example, differently from e.g. Bauer (2009), a non-adjacent genitive in a NAG sequence is not classified as discontinuous with respect to its head, and is therefore included in the corpus.

Secondly, as in Bolkestein $(1998,2001)$, some DP-external elements have not been considered as inducers of real syntactic discontinuity: this is the case of discourse particles typically occurring in the second position of the sentence (e.g. autem, enim, quidem, vero), of some forms of the personal pronouns (those with a purely anaphoric function, not introducing a new referent, a contrastive topic or a focused element), and of forms of the copula esse. The position of these elements is not entirely determined by syntactic structure, but is influenced by phonological and prosodical factors (cf. Adams 1994a,b on the placement of the copula and of unstressed personal pronouns, and the recent evaluation in Bauer 2009, 294-299, concerning 'second-position' placement in Latin).

In light of these criteria, discontinuous constituents in the Latin Gospels are very few. They are excluded because the basic pre- or post-nominal position of genitives cannot be safely assessed, and a decision in this respect would be dependent on theory-internal considerations; the same can be said in the case of ellipsis of the head noun (1e).

\section{[2] THE DATA FROM THE LATIN GOSPELS}

In this section I present the data on the distribution of genitive constituents that I collected for the Vulgata translation of the four Gospels. The main goal here is to summarize to what extent the Latin variety employed in these texts differs from the Classical one with respect to DP-internal syntax. In section [3] I will discuss

[4] A reviewer points out that a looser semantic relationship of some genitives with the head noun may result in a looser syntactic cohesion of the nominal constituents which host them. This perspective has been explored in its typological implications by Koptjevskaja-Tamm (2005), and in reference to Latin by Lehmann (1991). My data on the nominal syntax of the Greek and Latin New Testament are not particularly telling in this respect, given the general cohesion observed in the nominal group. However, a difference in distributional constraints between argumental and non-argumental genitives is certainly observable in Classical Latin, cf. Gianollo (2005). 


\begin{tabular}{llr}
\hline Genitives & NG & \multicolumn{1}{c}{ GN } \\
\hline Evangelium sec. Matthaeum & $577(97.1 \%)$ & $17(2.9 \%)$ \\
Evangelium sec. Marcum & $267(97.1 \%)$ & $8(2.9 \%)$ \\
Evangelium sec. Lucam & $572(97.9 \%)$ & $12(2.1 \%)$ \\
Evangelium sec. Ioannem & $322(94.1 \%)$ & $20(5.9 \%)$ \\
\hline
\end{tabular}

TABLE 1: Position of genitives in the Latin Gospels

possible translation effects on these constructions, by means of a systematic comparison with the Greek original, and in section [4] I will shortly present the data coming from other diastratically and/or diachronically comparable 'native' (nontranslated) Latin texts.

\section{[2.1] Genitives}

Table 1 shows the data relative to the position of genitive constituents with respect to the head noun in the four Latin Gospels.

In Gianollo (2007) I report data from Classical Latin texts, which, when compared to the situation found in the Vulgata, allow one to single out two crucial structural differences:

a) Whereas Classical Latin had a 'mixed' system of equally possible pre- and postnominal orders, the Latin found in the Vulgata has overwhelmingly shifted towards the post-nominal construction. It is particularly relevant that the observed shift in positioning does not correlate with a change in morphological marking, since the inflectional system is intact.

b) Whereas in Classical Latin two arguments of the same head noun could be simultaneously expressed (i.e. a genitive of the subject and a genitive of the object could co-exist within the same DP), this possibility has been lost in the Latin found in the Vulgata. ${ }^{5}$

The mixed NG/GN system of Classical Latin has been investigated from a variety of perspectives, and a number of factors governing the distribution of genitives have been singled out, having to do with syntactic constraints on the relative ordering of arguments, semantic cohesion, information structure, structural complexity of the genitive constituent, prosody, stylistic effects. ${ }^{6}$ None of these factors, however, has proved to be bounding with respect to a pre- or post-nominal positioning

[5] But cf. discussion in [2.2] and [3.3].

[6] Cf. most prominently Marouzeau (1922), Adams (1976), de Jong (1983), Pinkster (1990), Elerick (1991), Bolkestein (1998), Devine \& Stephens (2006), Bauer (2009), Viti (2010), Magni (2011). 


\begin{tabular}{llc}
\hline Possessive adjectives & $\mathrm{NG}^{\mathrm{agr}}$ & $\mathrm{G}^{\mathrm{agr}} \mathrm{N}$ \\
\hline Evangelium sec. Matthaeum & $371(98 \%)$ & $8(2 \%)$ \\
Evangelium sec. Marcum & $149(98 \%)$ & $3(2 \%)$ \\
Evangelium sec. Lucam & $337(97.4 \%)$ & $9(2.6 \%)$ \\
Evangelium sec. Ioannem & $210(91.3 \%)$ & $20(8.7 \%)$ \\
\hline
\end{tabular}

TABLE 2: Position of possessive adjectives in the Latin Gospels

of genitives. What is particularly relevant for our present purposes is that in Classical Latin (i) any argument of the head noun could be expressed either by a prenominal or by a post-nominal genitive (cf. Gianollo 2005, 57-64); (ii) informational focus could be connected to either the pre- or the post-nominal position. Devine \& Stephens (2006, 380-384) argue for the existence of two basic positions for Classical Latin genitives-one pre-nominal and one post-nominal-and of a third, derived position reached by a pragmatically motivated leftward movement of the genitive constituent. They notice, however, that ' $[\mathrm{i}] \mathrm{n}$ fact, it is almost the case that any pragmatic value can occur in any of the three posited syntactic positions, whether the complement moves or not.' (Devine \& Stephens 2006, 380).

These observations on the Classical Latin system take us back to the problem of Jerome's multifaceted competence, discussed in section [1.2]. As an accomplished speaker educated in the classicist rhetorical tradition, he had perfect command of the factors mentioned above, and this is apparent in his original literary production, where NG and GN orders alternate to a ratio comparable to that of Classical Latin documents (cf. the data in section [4]). However, in principle, a text in which any argumental relation and any pragmatic value were expressed by a post-nominal genitive was compatible with his core Classical Latin grammar, although far from the learned stylistic register. What has to be assessed is why Jerome opts for the almost univocal post-nominal positioning of genitives in the Vulgata. I will propose an answer to this question by evaluating first the extent of parallelism with respect to the Greek original (section [3]) and secondly the overlapping with some contemporary native Latin texts (section [4]). Before proceeding with these steps, I present below the data concerning possessive adjectives in the Vulgata.

\section{[2.2] Possessive adjectives}

The distribution of possessive adjectives in the four Latin Gospels is shown in Table 2. This table shows that, in the Latin of the Vulgata, the pre-nominal positioning of the possessive adjectives clearly represents a marked order. This tendency was already observable in earlier Latin texts: in Petronius' Satyricon, for instance, postnominal possessive adjectives are $84 \%$ of the total, and they reach $90 \%$ in the episode 
of the Cena Trimalchionis (cf. Gianollo 2005, 123-127). ${ }^{7}$

The situation is paralleled by the Greek, where the possessive adjective proper, however, has become extremely rare and is normally substituted by the genitive form of personal pronouns and of aủ tó (cf. section [3.3]).

The possibility of coordinating a possessive adjective with a nominal genitive suggests that they occupy the same structural position, the possessive adjective being only morphologically distinct in virtue of its sharing agreement features with the head noun:

(4) a. conservus tuus sum et fratrum tuorum

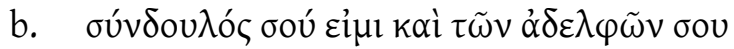

'I am a fellow servant with you and your brethren' (Rev 19:10)

(5) Deus tuus et seminis tui post te

'God to you and to your descendants after you' (Gn 17:7)

(6) possessio tua et filiorum tuorum

'an inheritance to you and to your children' (Josh. 14:9)

However in the Gospels there is an instance in which a post-nominal possessive adjective co-occurs with a non-coordinated post-nominal genitive, both in Latin and in Greek, thus representing an exception to the ban on double argument realization observed otherwise:

a. sanguis meus novi testamenti

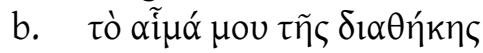

'my blood of the covenant' (Mt 26:28, Mk 14:24)

It may be noticed that part of the Greek manuscript tradition-most notably, the received Byzantine text accepted by the Greek Orthodox Church-inserts a doubled determiner ( $\tau$ ò) before the full genitive in (7), a fact which perhaps could hint to the uneasiness of the reader when faced with this rare construction. I will come back to this problem in section [3.3], when a clearer picture of the syntax of pronominal genitives in Greek will have emerged.

\section{[3] THE GREEK ORIGINAL AND TRANSLATION EFFECTS}

\section{[3.1] Distinguishing translation effects}

Quantitative studies on translation effects in biblical texts, such as e.g. Nunnally (1992) and Taylor (2008) for English, have shown that contact effects of translation on native constructions do not usually bring about real syntactic borrowing, but

[7] Interestingly, in Petronius the shift affecting the positioning of possessive adjectives does not correlate with a parallel shift for nominal genitives, which still show the even pre- vs. post-nominal distribution observed in Classical texts. 
have a potentially significant statistical import on the frequency of certain constructions. Taylor (2008) distinguishes between two different phenomena, direct and indirect translation effects. Direct effects amount to the exact reproduction of a matching structure, with outcomes ranging from ungrammatical glossing to frequency enhancement of a native construction. Indirect effects result in the priming of a particular construction, even in absence of a direct matching source for each instance in the translated text, and thus, again, in frequency enhancement. Since, as we will see, in our sample Latin genitive constructions almost always find a straightforwardly matching structure in the Greek original, we will be mainly concerned with direct translation effects: in order to assess their impact, in the following paragraphs the Latin order of genitives and possessive adjectives will be systematically compared with the Greek model.

Before going to the data, however, I will shortly discuss an important aspect of what Jerome himself says with respect to his translation technique and the more general debate between the sensus pro sensu and the verbum pro verbo approach.

It is well known that what Jerome does in his translation practice does not always correspond to the criteria that he explicitly declares in his works (cf. the comments in Brown 1992, 104-120). From his statements on translation technique, it appears that 'Jerome had two sets of principles for translating literature into Latin: one for the Bible, where a word for word rendering was required, and one for other literature, where a sense for sense translation was needed.' (Brown 1992, 109). ${ }^{8}$ However, while the second set of principles is more thoroughly respected, the difficulty in the application of the stricter requirements imposed on Bible translation appears clearly from the study of Jerome's actual practice, which highlights a number of factors (the nature of the languages, the classical rhetorical tradition, and theological considerations in primis) which would lead Jerome to abandon the word for word translation in some passages (cf. again Brown 1992, 111-120). What is evident from Jerome's practice and from his declarations is that the respect for the language into which the text is translated is a fundamental necessity, coming second only to the preservation of sense:

(8) Eadem igitur interpretandi sequenda est regula, quam saepe diximus, ut, ubi non fit damnum in sensu, linguae, in quam transferimus, घủ $\varphi \omega v i ́ \alpha$ et proprietas conservetur

[8] The most famous statement in this respect is contained in the Epistula 57, also known as Liber de optimo genere interpretandi: Ego enim non solum fateor, sed libera voce profiteor me in interpretatione Graecorum absque scripturis sanctis, ubi et verborum ordo mysterium est, non verbum e verbo, sed sensum exprimere de sensu.'I not only admit but proclaim freely that when translating from Greek (except in the case of holy scripture, where even the order of the words is a mystery) I translate sense for sense and not word for word' (Hier. Ep. 57.5.2; transl. Brown 1992, 105). 
'However, we should always follow the rule which I have repeated so often; viz. that where there is no difference in the sense, we should translate idiomatically and use euphonious language' (Hier., Ep. 106.55; transl. Brown 1992, 115)

A passage in the Liber de optimo genere interpretandi on the necessity to cope with sometimes irreducible differences between languages is particularly relevant here:

(9) Quanta enim apud Graecos bene dicuntur, quae, si ad verbum transferamus, in Latino non resonant, et e regione, quae apud nos placent, si vertantur iuxta ordinem, apud illos displicebunt!

'There are many phrases which are charming in Greek, which, if translated word for word, do not sound well in Latin; and conversely there are many which are pleasing to us in Latin which-assuming that the word order is not altered-would not please in Greek.' (Hier., Ep. 57.11.4; transl. Brown 1992, 107)

The statements above confirm the assumption guiding this work, namely that Jerome reviewed the Latin translations of the Gospels accepting in his version only constructions which he considered to be grammatical according to his native competence. We may therefore exclude, in principle, heavy borrowing of foreign syntactic constructions in the translation of genitive structures. In sections [3.2]-[3.3] I will try to show that this expectation is, in fact, borne out by the analysis of the data, and there is no syntactic interference in this respect. What we might expect, instead, is some degree of interference in the enhancement of the frequency of native constructions. In this case, however, we must ascertain whether the rise in frequency happens unconsciously in the practice of translation or is rather due to another kind of effect, syntactic imitation, i.e. to an artistic or more broadly ideological choice ('the Biblical style'), influenced by the prestige of the model. Finally, by means of comparison with native texts, we want to understand to what extent the effects above are made possible by syntactic convergence, i.e. by parallel developments of Latin and Greek, which enable the translation language to match corresponding structures in the model thanks to a pre-existing similarity in its native grammatical resources. After discussing the data in the next paragraph, in section [4] I will present my conclusions on these issues.

\section{[3.2] Genitives}

In this section I will deal with two classes of data: first, I will comment on the results of the parallel examination of genitive ordering in the Greek and Latin version of the Gospel of John and on this basis I will analyze Latin post-nominal constructions in relation to their model; then, I will concentrate on the pre-nominal instances found in the four Latin Gospels, in order to better understand the factors which lead the 
Latin translation to deviate from the unmarked post-nominal order.

The first observation which stems from the comparison of the Greek and Latin texts is that the presence of the overt definite determiner in Greek facilitates the structural analysis of Greek genitives: the article in definite DPs represents a useful 'place-marker' which delimitates phrase boundaries, thus helping distinguish various structural sources for genitive constituents. We can, in fact, identify four constructions, all of which were also possible in Classical Greek (cf. Manolessou 2000):

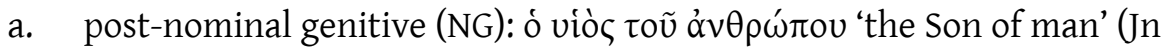 12:34)

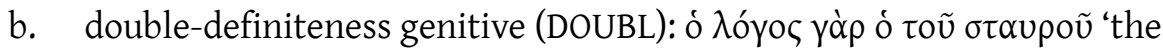 word of the cross' (1Cor 1:18)

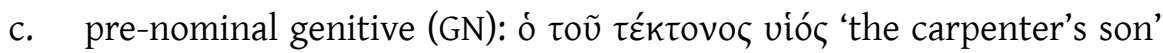 (Mt 13:55)

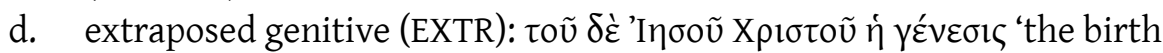 of Jesus Christ' (Mt 1:18)

In Table 3 I classify the Greek data coming from the Gospel of John according to these four categories (abbreviated, respectively, NG, DOUBL, GN, EXTR), and the Latin data according to the usual NG/GN distinction (repeated from Table 1). It could well be that the situation is more complex also in the case of Latin genitives, and that at least the pre-nominal ones originate from two different structural sources, a basic DP-internal pre-nominal position and a derived DP-peripheral one. In fact I defend this thesis for Late Latin in Gianollo (2005), and a similar proposal by Devine \& Stephens (2006) concerning Classical Latin has been mentioned in [2.1]. Since, however, Latin has no such place-marker as the Greek definite article, we can only be sure that we are dealing with extraposition when the DP is discontinuous. This is true also for Greek constructions occurring in indefinite DPs or in predicative position, where there is no article: they will be counted by default into the NG and GN categories, as there is usually no way to distinguish them from the EXTR and DOUBL constructions.

Due to our focus on the Latin translation, Table 3 operates a somewhat arbitrary distinction, from the point of view of Greek, in that it does not take into account the genitive of personal pronouns, which corresponds to a possessive adjective in Latin (see [3.3]). Accordingly, also genitive forms of the pronoun aủtós are counted here only when they are translated by genitive forms of the pronoun is and not by suus.

The difference of 4 between the totals is due to the fact that Latin (i) in two cases has a genitive construction translating a Greek lexeme with no parallel in Latin

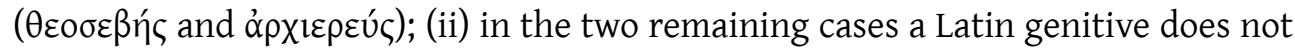
correspond to a Greek one due to syntactic reasons independent of genitive syntax 


\begin{tabular}{cccccc}
\hline Greek $(\mathrm{n}=338)$ & & \multicolumn{3}{c}{ Latin $(\mathrm{n}=342)$} \\
\hline $\mathrm{NG}$ & DOUBL & GN & EXTR & NG & GN \\
304 & 0 & 7 & 27 & 322 & 20 \\
\hline
\end{tabular}

TABLE 3: Translation of Greek genitives: the Gospel of John

proper. ${ }^{9}$

We can already see from Table 3 a first important aspect in which the Latin translation keeps faithful to the original: it uniformly chooses a genitive construction when the Greek has one. A more fine-grained analysis is in order, to evaluate the faithfulness with respect to word order in this domain.

\section{Post-nominal orders}

In principle, Latin NG orders could either correspond to a NG construction (10a) or to a double-definiteness genitive (10b) in Greek. However, the latter type is not attested in the Gospel of John, and is overall very rare in New Testament Greek (cf. Blass \& Debrunner 1961, 142). ${ }^{10}$ Double definiteness is instead quite frequent with possessive adjectives, as will be discussed in [3.3].

In the Gospel of John, the cases in which there is disagreement between Latin and Greek with respect to post-nominal genitives, i.e. the cases in which a NG order in the Latin translation corresponds to a GN order in the Greek, are 16 (4.7\% of the total Latin genitives). Of these, only 2 are represented by full nominal genitives; the other 14 are all genitive forms of the pronouns aủtós/is. The constructions in which they occur in the Greek belong to the extraposed type in 13 of the cases (the remaining case is found in a determinerless DP in predicative position, and cannot be safely analyzed as extraposed). The Greek pre-nominal construction involving

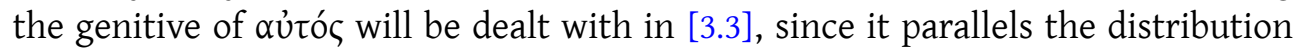
of enclitic genitives of the personal pronouns. For the moment let us conclude by noticing, once again, the substantial faithfulness of the Latin translation, but also the fact that Latin presents a higher number of post-nominal orders: importantly, the difference is mainly due to the preference for a post-nominal positioning of the genitive of $i$.

[9] In Jn 18:26, there is incorporation of the relative in Greek: Lat. eius cuius corresponds to Greek oṽ. In Jn 21:2

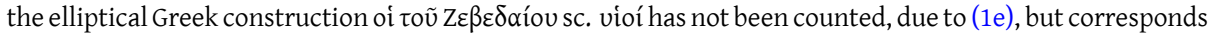
to a NG construction in Latin, filii Zebedaei.

[10] The doubled determiner introducing a genitive, still common in Classical Greek, has not survived in Modern Greek, which instead frequently employs double-definiteness constructions with adjectival modifiers. 


\begin{tabular}{lccc}
\hline Prenominal genitives & total & comparable & different order \\
\hline Evangelium sec. Matthaeum & 17 & 10 & 2 \\
Evangelium sec. Marcum & 8 & 5 & 0 \\
Evangelium sec. Lucam & 12 & 4 & 1 \\
Evangelium sec. Ioannem & 20 & 19 & 1 \\
\hline
\end{tabular}

TABLE 4: Prenominal genitives in the Latin Gospels

\section{Pre-nominal orders}

Pre-nominal genitives, as stated in section [2.1], represent the marked order in Latin. The comparison with the original of the Gospel of John in Table 3 (on page 88) has highlighted a similar ratio for Greek as well. Table 4 shows the results of a comparison between the Latin GN orders and the correspondent Greek structures in all the Gospels.

Sources of variation with respect to the model here are twofold: (i) in some cases Latin has a pre-nominal genitive which does not correspond to a genitive construction in Greek; (ii) when there is a matching Greek genitive, in a handful of cases Latin changes the order with respect to the model, opting for a GN construction.

The cases in which a Latin pre-nominal genitive is not comparable with a genitive construction in Greek are interesting from the point of view of translation technique. All but one case among the collected instances fall into two categories, which are determined by lexical factors:

a) cases in which a Greek term is properly translated into Latin with a lexical-

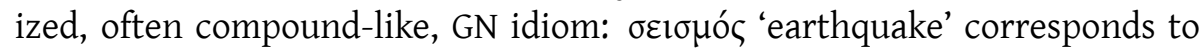

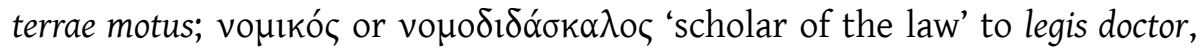
legis peritus; $\dot{\alpha} \lambda \varepsilon \kappa \tau$

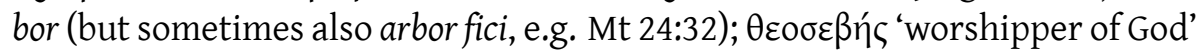
to Dei cultor. Out of the total 19 incomparable GN constructions in Latin, 16 (84.2\%) belong to this type (all instances in Luke and John receive this explanation).

b) cases in which there is lexical incompatibility beyond the DP-domain, namely Latin does not have a verb which translates the Greek one and the translator is forced to use a periphrasis. There are two instances of this kind: Mt 9:20

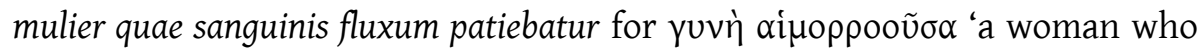
had suffered from an hemorrhage'; Mt 16:26 animae vero suae detrimentum pa-

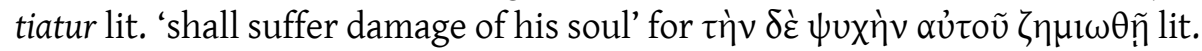
'shall be damaged in his soul'. 
A genuine syntactic motivation is more likely to underlie the remaining case:
a. omnis Iudaeae regio
'all the country of Judaea'

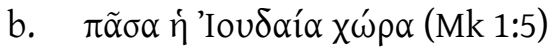

In (11a) the Latin translates with an epexegetical genitive a Greek geographical adjective. It is plausible that the Latin genitive is pre-nominal to parallel the Greek word order. In other passages, similar constructions are rendered with an adjec-

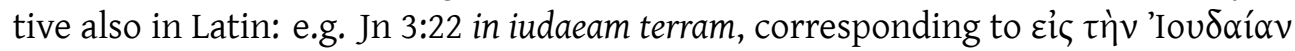
$\gamma \tilde{\eta} v$. The epexegetical genitive with place names is quite frequent in the Latin of the Vulgate, and alternates with the more Classical appositional construction (cf. in the same passage Mk 1:5 in Iordane flumine), with which it started to compete since late Republican times (Ernout \& Thomas 1953, 42). ${ }^{11}$

In the few instances in which the Latin GN corresponds to a NG order in Greek, the contexts in which the expressions appear suggest a motivation of genitive preposing in terms of information-driven displacement. Take for instance the case in (12):
a. Si praecepta mea servaveritis manebitis in dilectione mea sicut et ego Patris mei praecepta servavi et maneo in eius dilectione

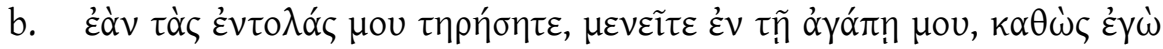

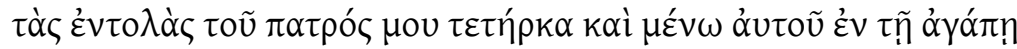 'If you keep my commandments, you will abide in my love, just as I have kept my Father's commandments and abide in his love.' (Jn 15:10)

In this passage, Jesus is contrastively comparing his own commandments to his Father's commandments, and his own love to his Father's love. In the Greek, only one of the semantically contrastive genitives is pre-nominal. The Latin version is more symmetrical in displacing both genitives to the left of the head noun.

On the other hand, also in this case, a post-nominal genitive would have been, in principle, possible in Latin, and it is not easy to understand why the strategy of genitive preposing is adopted by the translation only in these few occurrences, and not in many other places where similar pragmatic conditions would have made it possible.

In the Gospel of John, where most instances of parallel GN orders are found, 11 out of the 19 comparable constructions are represented by forms of the pronoun àviós translated by Latin eius/eorum. In these cases, differently from what we have

[11] As a reviewer correctly notes, cases of this kind are particularly tricky with respect to the distinction between argumental and non-argumental, modifier-like genitives. In fact, as we just saw, these constructions were preferably expressed with an adjective in Classical Latin, and in the language of the Vulgate they alternate between a genitival and an adjectival realization. Although their syntactic status is not entirely clear, I preferred to include them in my corpus in order not to run into the risk of underestimating the number of GN orders. 
seen in the section on post-nominal orders (page 88), the translator chooses to conform to the Greek construction, which is always of the extraposed type and involves cliticization to a DP-external host. The uneven behavior of the Latin translation in this respect is likely to be due to the syntactic nature of the extraposed genitive in New Testament Greek, which is fundamentally alien to the Latin system, as will be argued in the next section.

\section{[3.3] Possessive adjectives}

The possessive adjectives, which were already rare in Classical Greek, have practically disappeared from the language of the New Testament. When they occur, they tend to have, as in Classical Greek, an emphatic meaning (cf. Humbert 1954, 60f., Blass \& Debrunner 1961, 148f.). ${ }^{12}$ The Gospel of John is noteworthy for retaining a relatively high number of possessive adjectives (32 in attributive function). A particularly interesting fact, which deserves further research, is that possessive adjectives clearly behave differently from nominal genitives in Greek: they only come in two of the configurations seen for genitives in (10), namely (i) prenominally, but always DP-internally (following the article); (ii) post-nominally, but only in the double-definiteness construction (i.e. if post-nominal they have to be preceded by the doubled article).

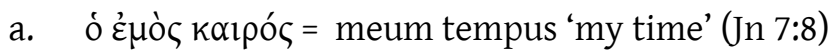

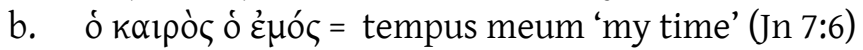

These observations suggest that Greek possessive adjectives have, in fact, an adjectival syntax: as in Classical Greek, an adjective in attributive function, if postnominal, must occur with a copy of the article of the matrix DP (if the DP is definite). Latin straightforwardly ignores the doubled determiner in these cases, recognizing in it a feature which is unamenable to the structure of its grammar (cf. Calboli 2009). Rather, the translation is sensitive to word order: in John, the Greek pre-nominal instances are paralleled by a Latin $G^{\text {agr }} \mathrm{N}$ order in all but one case; the same can be said for the post-nominal constructions, which match with just one exception.

In the great majority of cases, however, Latin possessive adjectives correspond to enclitic genitive forms of the personal pronouns or, in the case of the third per-

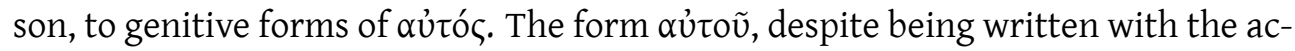
cent, displays a clitic behavior (cf. Horrocks 2007, 623): this is evident, for instance,

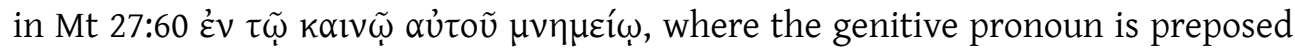
due to its cliticization to the adjective. No special emphasis on the pronoun-which would otherwise suggest a movement driven by information structure-is, in fact, detectable, and the Vulgate here answers with an unmarked post-nominal construc-

[12] In even rarer instances, the adjective ǐ $\delta$ เo is used to express possession, and is translated in Latin by either proprius or suus. 
tion (in monumento suo novo). Blass \& Debrunner $(1961,148)$ state that the positions available for the enclitic genitive pronouns in New Testament Greek are the same as in Classical Greek: they either occur immediately after the noun (with no repetition of the article), or surface pre-nominally in case another pre-nominal modifier, to which they can cliticize, is present. They can also precede the determiner of the matrix DP, cliticizing to DP-external elements.

Interestingly, an increase in the frequency of the latter structure is evident in New Testament Greek. Our data on the Gospel of John show that, for the first and second person, there are 26 pre-nominal instances analyzable as extraposition. Moreover, out of the 27 extraposed genitives of Table 3, 24 are represented by forms of aútóc. In these cases the extraposition is best analyzed in terms of cliticization to a DP-external host (but see Gianollo In press for the complex interplay of prosodic, syntactic, and semantic factors).

Horrocks $(2007,628 f$.) comments on this construction and attributes to it a very crucial role in the diachronic process leading to the demise of the dative and the rise of genitive forms to express indirect objects in Greek: genitive clitics, properly belonging to the thematic grid of the noun, in cliticizing to the verb preceding the DP would end up in the position typically occupied by direct and indirect objects. An increase in the construction in post-Classical Greek would have led to a reanalysis of the genitive clitic as performing the function of an 'ethical' dative (dativus commodi et incommodi), thus paving the way to the generalized substitution of morphologically genitive to morphologically dative forms. The example in (14) clearly shows a possible 'bridging context' already in Classical Greek:

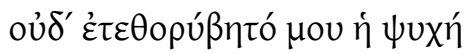

'nor did my soul become agitated' (Plato, Symp. 215e)

Example (15) represents a clear-cut case from New Testament Greek in which an 'ethical' interpretation of the displaced genitive clitic is likely:

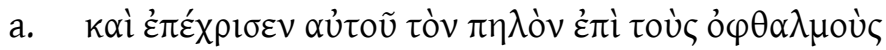
b. et linuit lutum super oculos eius 'and anointed the man's eyes with the clay' (Jn 9:6)

A similar analysis of the genitive constituent seems to hold also in some, much rarer cases where a full nominal genitive is extraposed, giving rise to the few instances of discontinuity found in the corpus:

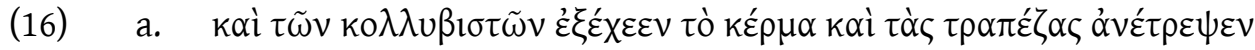

b. et nummulariorum effudit aes et mensas subvertit 'and he poured out the coins of the money-changers and overturned their tables' (Jn 2:15) 
In light of the ban on multiple genitive realization within a DP observed in Modern Greek and apparently active already in New Testament Greek, it is possible that also in complex structures as e.g. in (17a) we are in fact dealing with a re-categorization of the genitive constituent as the indirect argument of the verb, and not with an instance of 'double genitive': 13

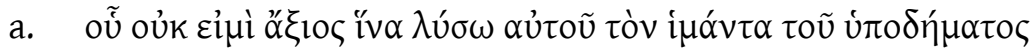
b. cuius ego non sum dignus ut solvam eius corrigiam calciamenti 'the thong of whose sandal I am not worthy to untie' (Jn 1:27)

The special behavior of clitic genitives takes us back to the exception to the restriction on genitive iteration discussed in [2.2]. If it is true that the example in (7) is distinct from the cases seen here, because (i) the clitic is internal to the DP, and (ii) an 'ethical dative' interpretation is out of the question, it is also remarkable that one of the genitives is represented by a clitic ( $\mu \mathrm{ov})$. Alexiadou (2009) notices that in Modern Greek, a language in which the ban on genitive iteration is otherwise active, the prohibition can be overcome if one of the arguments is realized by a pronominal clitic. It seems, therefore, that the special syntactic behavior of clitics allows them to escape the boundaries imposed on the realization of multiple adnominal arguments by some grammatical systems.

In the Latin translations (16b)-(17b) the Vulgate reproduces the exact linear order found in Greek. However, this is not the general tendency: we have already seen in section [2.1] for the instances involving aưtó s that in half of the cases the Latin does not follow the Greek order. This, is, in fact, the syntactic domain where the greatest amount of variation with respect to the model is observable in the Latin text.

The Latin reaction to this kind of constructions seems to hint to the translator's awareness of the irreconcilable difference between the two languages in this respect. Further support to this impression also comes from cases in which a morphologically dative constituent, which can be interpreted as a dativus commodi, is rendered in Latin with a possessive adjective. This shows that the translator is sensitive to the semantic similarity between some Greek datives and certain genitives, and reacts according to his native grammar:

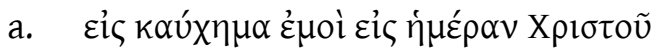
b. ad gloriam meam in die Christi
'for my glory in the day of Christ' (Phil 2:16)

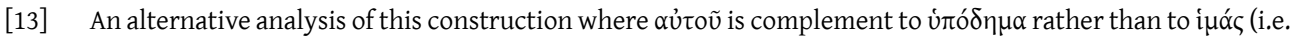
'the strap of his sandal' rather than 'his sandal strap') is also possible. It is certainly the correct analysis

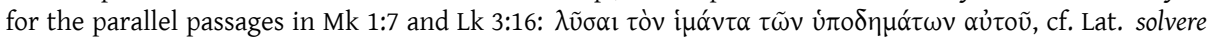
corrigiam calciamentorum eius. 
When dealing with a construction clearly extraneous to the Latin grammar the translator is not behaving slavishly with respect to the model, but shows the ability to find a compromise, sacrificing the semantic nuance of 'affectedness' expressed by the Greek extraposed constructions in order to preserve the propriety of its native language.

In the case of the 'ethical' extraposed genitive of the Greek, thus, we witness a situation in which the Latin translation, in a remarkable number of cases, puts grammatical propriety before faithfulness to the model.

\section{[4] IMITATION, INTERFERENCE, PARALLEL DEVELOPMENT?}

In the previous paragraph, we have singled out a syntactic context in which the Latin translation and the Greek original show a remarkable number of discrepancies with respect to the ordering of genitives. We have explained such discrepancies by arguing that, while the two languages have substantially parallel resources for the realization of genitives DP-internally, they differ in the way in which genitives interact with clausal syntax. Namely, in New Testament Greek, genitives (most often pronominal ones) may be extracted out of the DP and end up in the position typically occupied by indirect objects. The Latin translator does not slavishly follow the Greek in this construction, which is alien to his native competence, but decides on a case-by-case basis, and deviates from the model significantly more often than in other contexts.

Having acknowledged a certain degree of autonomy of the Latin translator in reacting to possible sources of syntactic interference, we are left with the overwhelming similarities that the Greek model and the Latin translation show in the domain of the syntax of adnominal genitives. To this we must add the substantial differences with respect to the syntax of genitives in Classical Latin. In this paragraph, I will present some data which will contribute to the evaluation of the role of syntactic imitation in bringing about the observed similarity, by comparing the situation found in the Vulgata to what is witnessed by contemporary non-translated Latin texts.

Many scholars have noticed and variously commented upon the remarkable differences in register in Jerome's production, in particular the major divide between Jerome's works as a translator of biblical texts and the rest of his literary corpus. This sort of observations contributed to strengthening the impression of artificiality raised in some philologists by the language of the Vulgata. A cursory comparison of the data coming from the Gospels with the distribution of genitives in texts belonging to Jerome's literary production will clarify the point.

The ratio of NG/GN orders in the small sample of Jerome's writings shown in Table 5 on page 95 is substantially the same as that found in Classical Latin. Also the relatively high rate of discontinuous constituents patterns with the Classical usage: there are respectively 9, 7 and 6 cases of genitive-noun discontinuity in the short 


\begin{tabular}{lll}
\hline Genitives & NG & GN \\
\hline Hier., Epistula CXXVII & $53(53.5 \%)$ & $46(46.5 \%)$ \\
Hier., Vita Malchi & $31(43 \%)$ & $41(57 \%)$ \\
Hier., De Viris Illustribus I-X & $80(60.6 \%)$ & $52(39.4 \%)$ \\
\hline
\end{tabular}

TABLE 5: Genitive orders in Jerome

\begin{tabular}{lll}
\hline Genitives & NG & GN \\
\hline Passio Perpetuae et Felicitatis & $101(84.2 \%)$ & $19(15.8 \%)$ \\
Peregrinatio Egeriae & $505(93.5 \%)$ & $35(6.5 \%)$ \\
\hline
\end{tabular}

TABLE 6: Genitive orders in Passio and Peregrinatio

texts presented above. Should we conclude that the shift towards the NG order that is typical of the Latin of the Gospels is uniquely due to the influence of the Greek model, and that Jerome in his translations is artificially imitating the Greek linear order for artistic and ideological reasons?

While it is impossible to approach the problem of Jerome's diglossia in a systematic way within the limits of this paper, it is useful to concentrate on another set of data, coming from two texts, the Passio Perpetuae et Felicitatis (beginning of the third cent. CE) and the Peregrinatio Egeriae (fourth cent. CE), which are examples of the 'new' sermo humilis, i.e. the colloquial sub-élite variety that at this stage diverged in many important respects from the standard language (cf. Clackson \& Horrocks 2007, 229-264).

Table 6 shows the overall distribution of genitives in the two documents.

These texts have been written by native speakers of Latin and are not translations. They display a distribution of genitives which patterns with the situation found in the Vulgate Gospels. The data from the Passio Perpetuae et Felicitatis are even more striking in this respect once the sections written by the narrator to introduce and conclude the work are separated from those written by the martyrs, as shown in Table 7.

\begin{tabular}{lcc}
\hline Genitives & NG & GN \\
\hline Narrator (1-2;14-21) & $57(79.2 \%)$ & $15(20.8 \%)$ \\
Perpetua (3-10) & $41(91.1 \%)$ & $4(8.9 \%)$ \\
Saturus (11-13) & $3(100 \%)$ & $0(0 \%)$ \\
\hline
\end{tabular}

TABLE 7: Genitive orders in the sections of the Passio 


\begin{tabular}{lll}
\hline Possessive adjectives & $\mathrm{NG}^{\mathrm{agr}}$ & $\mathrm{G}^{\mathrm{agr}} \mathrm{N}$ \\
\hline Passio Perpetuae et Felicitatis & $45(86.5 \%)$ & $7(13.5 \%)$ \\
Peregrinatio Egeriae & $96(95 \%)$ & $5(5 \%)$ \\
\hline
\end{tabular}

TABLE 8: Possessive adjectives in Passio and Peregrinatio

The fact that the narrator employs pre-nominal genitives more often can be attributed to his desire for an elevated style, complying with the standard rhetorical rules; it is probably not accidental that also Perpetua's pre-nominal genitives occur only in the beginning and closing paragraphs of her narration. In both the Passio and the Peregrinatio, many of the pre-nominal orders are found in formulaic expressions (e.g. turbarum beneficio 'to the benefit of the crowd' (Passio 3.6), pullorum cantus 'cockcrow' (Per. Eg. 36.1), loci notiores 'accustomed to the place' (Per. Eg. 16.3)). A parallel situation is found with possessive adjectives, as shown in Table 8.

No instances of multiple genitives, i.e. of the simultaneous expression of two arguments of the same head, are found in the texts. Discontinuity between a genitive and its head noun is a rare phenomenon: there are only 3 cases in the Passio and 8 cases in the Peregrinatio, in all of which the element inducing discontinuity is a verbal form. In general, the internal syntax of the DP is quite simple, but there are examples of more complex structures, where genitives co-occur with adjectives modifying the head noun and with functional items such as demonstratives and quantifiers. While elements like adjectives, demonstratives, quantifiers have a distribution that is comparable to the Classical Latin situation (cf. Gianollo 2005, 170-179 for a more comprehensive analysis of these aspects in Egeria's DP syntax), genitives and possessive adjectives have steadily shifted towards the post-nominal position.

The data thus indicate that the post-nominal positioning of genitives is a major real change in the history of Latin: texts which are not stylistically informed by classicist stylistic rules, but rather reproduce the evolving colloquial language and find their formal model in the style of the sacred texts and of the Church Fathers, witness a clear-cut trend in this respect. Adams (1976) suggests that this trend may have started even earlier, during the second century CE. In Gianollo (2007) I have proposed to analyze the outcome of this massive shift in terms of a parameterresetting operation which involves a reanalysis of the Classical Latin post-nominal construction, and which brings about, among other things, a more fixed position for the genitive constituent and its non-reiterability. I have also proposed that the parallel development of post-nominal genitives in the Romance languages might receive a principled historical explanation by assuming that the late variety of Latin overwhelmingly characterized by the NG order is, in fact, the precursor of the early Romance varieties (cf. Gianollo 2009 on Old French). Due to the focus of this paper, 
I refer to these previous works for the argumentation. Here, abstracting away from the structural analysis, it is sufficient to notice the loss in variability affecting the linear distribution of genitives.

In light of the data coming from earlier and contemporary native texts, which show the same distribution of genitives and possessive adjectives as that found in the Latin translation of the Gospels, the most plausible hypothesis with respect to the syntax of adnominal arguments in the Vulgata is to assume that the translator does not mechanically reproduce the Greek linguistic model, but makes use of the remarkably similar structures provided by his native grammar, or at least by the native grammar of the greatest part of his audience. The respect for the model constrains the translator in the application of the conservative register belonging to the classical rhetorical tradition, and guides him towards a new Christian style, based on the sermo humilis.

\section{[5] CONCLUSION}

The comparison between the Latin Vulgata translation of the Gospels and the Greek original has highlighted a substantial parallelism in the realization of adnominal arguments, but has also singled out a domain-clitic 'ethical' genitives-in which the Latin translator does not straightforwardly follow the Greek. This fact has been explained by noticing that, while in other aspects of the syntax of genitives Greek and Latin share very similar resources, this specific construction is alien to the native grammar of Latin, and forces the translator to diverge from the model in many cases.

Secondly, I have tried to show that DP-internal syntax in the Vulgata translation of the Gospels displays the same features of native Late Latin texts with respect to the realization of adnominal arguments. I have therefore proposed that the parallelism with the Greek original in DP-internal word order might be due to the application of a 'new' genuine variety of Latin, and not primarily to imitation of the Greek model.

If this conclusion can be accepted, the next problem to address is how to explain the actual similarities observable in the new Late Latin grammatical system and in the Greek koiné represented e.g. by the New Testament, which also shows, in comparison to Classical Greek, a shift from a 'mixed' NG/GN system to a uniformly NG one (transmitted to Modern Greek). Namely, are these similarities due to syntactic interference (i.e. to the effect of extensive contact and bilingualism) or rather to syntactic convergence (i.e. to independent parallel developments)? An answer to this question is beyond the limits of the present contribution, but is of extreme importance for our knowledge of the history of Greek and Latin, and for our understanding of the role of contact in language change. 


\section{ACKNOWLEDGEMENTS}

I wish to thank the audience of the International Workshop on Indo-European Syntax (Athens, GA, May 13-15 2009), Artemis Alexiadou, Gualtiero Calboli, Giuseppe Longobardi, and two anonymous reviewers for their useful comments on various aspects of this paper.

\section{REFERENCES}

Adams, James Noel. 1976. A typological approach to Latin word order. Indogermanische Forschungen 81. 70-99.

Adams, James Noel. 1994a. Wackernagel's Law and the placement of the copula esse in Classical Latin. Cambridge: Cambridge Philological Society.

Adams, James Noel. 1994b. Wackernagel's Law and the position of unstressed personal pronouns in Classical Latin. Transactions of the Philological Society 92.103-178.

Adams, James Noel. 2003. Bilingualism and the Latin language. Cambridge: Cambridge University Press.

Aland, Kurt \& Barbara Aland. 1989. The text of the New Testament. Grand Rapids: Eerdmans.

Alexiadou, Artemis. 2009. Adnominal arguments and Case in the DP. Paper presented at the Fachbereichskolloquium, July 9, 2009. University of Konstanz.

Bauer, Brigitte L. M. 2009. Word order. In Philip Baldi \& Pierluigi Cuzzolin (eds.), New perspectives on historical Latin syntax. Vol. 1. Syntax of the sentence, 241-316. Berlin: Mouton de Gruyter.

Blass, Friedrich \& Albert Debrunner. 1961. A Greek grammar of the New Testament and other early Christian literature. Translated and revised by Robert W. Funk. Chicago: The University of Chicago Press.

Bolkestein, Machtelt. 1998. Word order variation in complex noun phrases in Classical Latin. In Benjamín García Hernández (ed.), Estudios de lingüística Latina. Actas del IX Coloquio Internacional de Lingüística Latina, 185-202. Madrid: Ediciones Clásicas.

Bolkestein, Machtelt. 2001. Random scrambling? Constraints on discontinuity in Latin noun phrases. In Claude Moussy (ed.), De lingua Latina novae quaestiones. Actes du Xème Colloque International de Linguistique Latine, 245-258. Louvain: Peeters.

Brown, Dennis. 1992. Vir trilinguis. A study in the Biblical exegesis of Saint Jerome. Kampen: Kok Pharos. 
Burton, Philip. 2000. The Old Latin gospels. A study of their texts and language. Oxford: Oxford University Press.

Calboli, Gualtiero. 2009. Latin syntax and Greek. In Philip Baldi \& Pierluigi Cuzzolin (eds.), New perspectives on historical Latin syntax. Vol. 1. Syntax of the sentence, 65-193. Berlin: Mouton de Gruyter.

Clackson, James \& Geoffrey Horrocks. 2007. The Blackwell history of the Latin language. Malden, MA: Blackwell.

Crisma, Paola \& Giuseppe Longobardi. 2009. Change, relatedness, and inertia in historical syntax. In Paola Crisma \& Giuseppe Longobardi (eds.), Historical syntax and linguistic theory, 1-15. Oxford: Oxford University Press.

Devine, Andrew M. \& Laurence D. Stephens. 2006. Latin word order. Structured meaning and information. Oxford: Oxford University Press.

Elerick, Charles. 1991. Latin noun/gen./adj. serialization and language universals. In Robert Coleman (ed.), New Studies in Latin linguistics. Selected papers from the 4th International Colloquium on Latin Linguistics, 311-321. Amsterdam: John Benjamins.

Elliott, James K. 1992. The translation of the New Testament into Latin: the Old Latin and the Vulgate. In Wolfgang Haase (ed.), Aufstieg und Niedergang der römischen Welt. vol. ii.26.1, 198-245. Berlin: Walter de Gruyter.

Ernout, Alfred \& François Thomas. 1953. Syntaxe latine. 2nd ed. Paris: Klincksieck.

Gianollo, Chiara. 2005. Constituent structure and parametric resetting in the Latin DP: a diachronic study: University of Pisa dissertation.

Gianollo, Chiara. 2007. The internal syntax of the nominal phrase in Latin. In Gérald Purnelle \& Joseph Denooz (eds.), Ordre et cohérence en latin, 65-80. Genève: Librairie Droz.

Gianollo, Chiara. 2009. Prepositional genitives in Romance and the issue of parallel development. Talk given at the XI Diachronic Generative Syntax Conference, University of Campinas, July 22-24, 2009. http://ling. uni-konstanz . de/pages / home/gianollo/Material/Gianollo2009-DIGSXIweb.pdf.

Gianollo, Chiara. In press. External possession in New Testament Greek. In Gualtiero Calboli \& Pierluigi Cuzzolin (eds.), Papers on grammar XI, Roma: Herder.

Giorgi, Alessandra \& Giuseppe Longobardi. 1991. The syntax of Noun Phrases. Configurations, parameters, and empty categories. Cambridge: Cambridge University Press. 
de Groot, Albert Willem. 1957. Classification of the uses of a case illustrated on the genitive in Latin. Lingua 6. 8-66.

Horrocks, Geoffrey. 2007. Syntax: From Classical Greek to the Koine. In AnastasiosPhoivos Christidis (ed.), A history of Ancient Greek. From the beginnings to Late Antiquity, 618-631. Cambridge: Cambridge University Press.

Humbert, Jean. 1954. Syntaxe grecque. 2nd ed. Paris: Klincksieck.

de Jong, Jan. 1983. Word order within Latin noun phrases. In Harm Pinkster (ed.), Latin linguistics and linguistic theory. Proceedings of the 1st International Colloquium on Latin Linguistics, 131-141. Amsterdam: John Benjamins.

Koptjevskaja-Tamm, Maria. 2005. 'Maria's ring of gold': non-anchoring relations in the European languages. In Jiyung Kim, Yuri A. Lander \& Barbara H. Partee (eds.), Possessives and beyond: Semantics and syntax, 155-181. Amherst MA: GLSA Publications.

Lehmann, Christian. 1991. The Latin nominal group in typological perspective. In Robert Coleman (ed.), New studies in Latin linguistics. Selected papers from the 4th International Colloquium on Latin Linguistics, 203-232. Amsterdam: John Benjamins.

Lightfoot, David. 2006. How new languages emerge. Cambridge: Cambridge University Press.

Magni, Elisabetta. 2011. Coexisting structures and competing functions in genitive word order. In Petra Sleeman \& Harry Perridon (eds.), The noun phrase in Romance and Germanic: Structure, variation and change, 223-240. Amsterdam: John Benjamins.

Manolessou, Io. 2000. Greek noun phrase structure: A study in syntactic evolution: University of Cambridge dissertation.

Marouzeau, Jules. 1922. L'ordre des mots dans la phrase latine. I. Les groupes nominaux. Paris: Champion.

Meershoek, Gerardus Q. A. 1966. Le latin biblique d'après Saint Jérôme: aspects linguistiques de la rencontre entre la Bible et le monde classique. Nijmegen: Dekker and van de Vegt.

Metzger, Bruce M. 1977. The early versions of the New Testament. Their origin, transmission, and limitations. Oxford: Clarendon Press.

Nestle, Eberhard, Erwin Nestle \& Kurt Aland. 1993. Novum Testamentum Graece. 27th ed. Stuttgart: Deutsche Bibelgesellschaft. 
Nunnally, Thomas E. 1992. Man's son/son of man: Translation, textual conditioning, and the history of the English genitive. In M. Rissanen, O. Ihalainen, T. Nevalainen \& I. Taavitsainen (eds.), History of Englishes, 359-371. Berlin: Mouton de Gruyter.

Pinkster, Harm. 1990. Latin syntax and semantics. London: Routledge.

Plater, William E. \& Henry J. White. 1926. A grammar of the Vulgate. Oxford: Clarendon Press.

Taylor, Ann. 2008. Contact effects of translation: Distinguishing two kinds of influence in Old English. Language Variation and Change 20.341-365.

Viti, Carlota. 2010. Observations on genitive word order in Latin. In Olga Spevak (ed.), Le syntagme nominal en latin. Nouvelles contributions. Actes de l'atelier du Centre Alfred Ernout, 77-96. Paris: L'Harmattan.

Weber, Robertus, Bonifatius Fischer, Herman Josef Frede, H. F. D. Sparks \& Walter Thiele. 1994. Biblia Sacra iuxta Vulgatam Versionem. Fourth revised ed. Stuttgart: Deutsche Bibelgesellschaft.

AUTHOR CONTACT INFORMATION

Chiara Gianollo

University of Konstanz

Department of Linguistics \& Zukunftskolleg

Fach 216

78457 Konstanz

Germany

chiara.gianollo@uni-konstanz.de 